\title{
Christine Ferlampin-Acher, Daphné dans les textes français du Moyen Âge: des amours réticents
}

\section{Paola Cifarelli}

\section{(2) OpenEdition}

1 Journals

\section{Édition électronique}

URL : https://journals.openedition.org/studifrancesi/26041

DOI : 10.4000/studifrancesi.26041

ISSN : 2421-5856

Éditeur

Rosenberg \& Sellier

\section{Édition imprimée}

Date de publication : 1 avril 2007

Pagination : 158

ISSN : 0039-2944

\section{Référence électronique}

Paola Cifarelli, «Christine Ferlampin-Acher, Daphné dans les textes français du Moyen Âge: des amours réticents », Studi Francesi [En ligne], 151 (LI | I) | 2007, mis en ligne le 30 novembre 2015, consulté le 23 novembre 2021. URL : http://journals.openedition.org/studifrancesi/26041 ; DOI : https://doi.org/ 10.4000/studifrancesi.26041

Ce document a été généré automatiquement le 23 novembre 2021.

\section{(c) $($ ) $\odot$}

Studi Francesi è distribuita con Licenza Creative Commons Attribuzione - Non commerciale - Non opere derivate 4.0 Internazionale. 


\title{
Christine Ferlampin-Acher, Daphné dans les textes français du Moyen Âge: des amours réticents
}

\author{
Paola Cifarelli
}

\section{RÉFÉRENCE}

CHRISTINE FERLAMPIN-ACHER, Daphné dans les textes français du Moyen Âge: des amours réticents, «Cahiers de l'Association Internationale des études Françaises» 58, 2006, pp. 291-308.

1 Après avoir rappelé la fortune modeste de Daphné dans la littérature médiévale, surtout par rapport à d'autres héros de la mythologie présents dans les Métamorphoses d'Ovide, l'A. s'arrête sur trois textes qui exploitent ce personnage au Moyen Âge finissant: l'Ovide Moralisé, le Joli Buisson de Jonece de Froissart et l'Epistre Othea de Christine de Pizan. Ensuite, elle réfute toutes les hypothèses qu'on pourrait formuler à propos de la rareté de ce personnage, à savoir le fait que son nom et son iconographie pouvaient se confondre avec celui d'autres personnages mythologiques, et l'incompatibilité du thème de la virginité avec l'univers romanesque.

En fait, bien que peu mentionnée explicitement, Daphné est bien présente dans l'imaginaire de l'homme médiéval; pour prouver ce concept, l'A. analyse en détail le lai de Narcissus, qui est une greffe entre le personnage de Narcisse et celui de Daphné. 